\title{
Impaired Financing Determinants of Islamic Banks in Malaysia
}

\author{
Alias Mat Nor, Nor Hayati Ahmad \\ MCRC Northern Region (Kedah/Perlis), Kedah, Malaysia \\ alias.matnor@muamalat.com.my
}

\begin{abstract}
Despite commendable growth of Islamic banking on a macro level, impaired financing is an issue among Islamic banks at the micro level. The 2008 Global Financial Crisis shows large credit risk was largely attributable to staff inefficiency. This study investigates the moderating effect of staff efficiency on determinants of credit risk or impaired financing of sixteen Islamic banks in Malaysia over the 2005-2013 periods. The determinants include new variables such as political stability index and corruption index besides GDP, inflation, finance to deposit, loan loss provisions, liquidity, capital, net interest margin, profitability, loan growth and net charge offs. The study highlights new findings where impaired financing reduced with higher political stability index and corruption index. Loan loss provision has significant positive whilst loan growth has negative impact on impaired financing. Staff efficiency significantly moderates the impaired financing relationship with capital ratio, profitability and loan growth. This relationship yields model fit of 0.889 . The results support Resourced - based Theory and provide statistical evidence of the importance of staff efficiency in managing banks' credit risk. None of the external factors had significant influence on impaired financing, which statistically proved that the profit and loss sharing concept of Islamic banking provides effective tool to mitigate external risks.
\end{abstract}

Keywords: Impaired financing, Islamic banks, macro level

\section{Introduction}

According to Ahmed (2009), the global financial crisis (GFC) that began around 2006, caused several countries like Greece, Portugal, Ireland and Spain into bankruptcy. Laeven and Valencia (2008) highlighted that GFC had caused many banks to face high credit risk due to over leveraging and speculative activities in mortgage markets. The GFC did not only destroy many mega banking institutions such as Northern Rock, Bear Stearns, Indy Mac Bank and Washington Mutual, but also caused misery to millions of American and European society (Ahmed, 2009). They found that non-performing loans or impaired financing caused 124 systematic banking crises over the period of 1970 to 2007 . Impaired financing leads to formation of credit risk. Credit risk reduces asset quality (Rose, 2002). The central bank of Malaysia defines impaired financing when principal or interest payment is three months or more in arrears (BNM, 2012). The consequences of impaired financing on bank are reductions in their profits or at times, lead to losses. As such, a bank managing their impaired financing from getting higher is a continuous challenging task. Ahmad and Ahmad (2004) study on the key factors influencing credit risk of Malaysian Islamic banks found out that Islamic banking credit risk remains relatively high despite the risk sharing between the bank and the clients. The factors studied are management efficiency, risky sector financings, property financings, capital to total assets, loan loss provision, funding cost, risk-weighted assets, and natural log of total asset and financing to deposit. In this study, the effects of four new variables such as political stability index, corruption control index, net charged off and staff efficiency on impaired financing of Islamic banks intend to fill the gap in Ahmad and Ahmad (2004).

Problem Statement: Chapra (2008) highlighted that Islamic banking system despite being acceptable as a better intermediation channel could not escape from incurring high impaired financing. Table 1 shows the average impaired financing albeit credit risk of Malaysian Islamic banks over 2005 to 2013 periods. This phenomenon indicates that there are still pertinent new factors that need to be examined besides those covered in past studies (BNM, 2013). Among the new factors, human resource efficiency is the most vexing managerial issue in Islamic finance system where lack of skills, knowledge and incompetence workforce will lead to higher operational and credit risks which stifle the Islamic banks' growth potential (Mohd-Sultan, 2008). The study provides fresh suggestion that the deterioration in financing quality of Islamic banks might have occurred due to lack of staff efficiency in terms of their credit assessment, apart from the influence of macro-economic factors. Meanwhile, Abd-Karim, Chan and Hassan (2010) highlighted that higher impaired financing or credit risk reduces cost efficiency and lead to inefficiencies in the banking sector. 
Table 1: Impaired Financing of Islamic banks in Malaysia

\begin{tabular}{|c|c|c|c|c|c|c|c|c|c|c|}
\hline BANK & $\begin{array}{l}2013 \\
(\%)\end{array}$ & $\begin{array}{l}2012 \\
(\%)\end{array}$ & $\begin{array}{l}2011 \\
(\%)\end{array}$ & $\begin{array}{l}2010 \\
(\%)\end{array}$ & $\begin{array}{l}2009 \\
(\%)\end{array}$ & $\begin{array}{l}2008 \\
(\%) \\
\end{array}$ & $\begin{array}{l}2007 \\
(\%)\end{array}$ & $\begin{array}{l}2006 \\
(\%) \\
\end{array}$ & $\begin{array}{l}2005 \\
(\%)\end{array}$ & $\begin{array}{l}\text { Average } \\
(\%)\end{array}$ \\
\hline Bank Islam & 1.18 & 1.55 & 2.61 & 4.50 & 12.70 & 18.60 & 22.30 & 22.57 & 19.95 & 11.77 \\
\hline Bank Muamalat & 2.54 & 4.79 & 5.04 & 7.30 & 9.46 & 9.15 & 10.40 & 6.60 & 6.78 & 6.89 \\
\hline RHB Islamic & 2.31 & 2.52 & 4.16 & 6.95 & 6.19 & 4.83 & 6.03 & 5.66 & 5.98 & 4.96 \\
\hline CIMB Islamic & 0.87 & 0.91 & 1.21 & 1.48 & 1.47 & 3.28 & 11.60 & 12.85 & 1.50 & 3.91 \\
\hline Maybank Islamic & 0.60 & 0.84 & 1.55 & 2.69 & 3.97 & 5.07 & n.a. & n.a. & n.a. & 2.45 \\
\hline Kuwait Fin House & 10.6 & 15.60 & 23.20 & 12.00 & 11.80 & 0.91 & 0.07 & 0.49 & 0.28 & 8.34 \\
\hline Affin Islamic & 2.15 & 2.49 & 3.86 & 4.19 & 2.05 & 1.61 & 1.73 & 2.75 & n.a. & 2.60 \\
\hline Am Islamic & 1.19 & 1.37 & 2.33 & 1.52 & 2.38 & 3.69 & 7.12 & n.a. & n.a. & 2.80 \\
\hline Alliance Islamic & 1.87 & 1.53 & 1.51 & 1.33 & 2.41 & 2.89 & n.a. & n.a. & n.a. & 1.92 \\
\hline HongLeong & 1.50 & 1.79 & 0.73 & 0.86 & 1.18 & 1.06 & 1.63 & 1.88 & n.a. & 1.33 \\
\hline Public Islamic & 0.90 & 0.86 & 0.89 & 0.98 & 0.92 & 1.16 & n.a. & n.a. & n.a. & 0.95 \\
\hline Asian Finance & 2.14 & 3.81 & 5.16 & 6.91 & 0.29 & 0.77 & 0.53 & n.a. & n.a. & 2.80 \\
\hline Al Rajhi Bank & 2.06 & 2.39 & 3.76 & 4.57 & 1.01 & 0.54 & 0.16 & 0.35 & n.a. & 1.86 \\
\hline OCBC Al-Amin & 1.56 & 1.26 & 1.46 & 1.78 & 2.45 & 2.00 & n.a. & n.a. & n.a. & 1.75 \\
\hline $\begin{array}{l}\text { StandChart } \\
\text { Saadiq }\end{array}$ & 0.79 & 0.84 & 0.63 & 0.94 & 0.72 & 0.67 & n.a. & n.a. & n.a. & 0.76 \\
\hline HSBC Amanah & 1.79 & 1.49 & 1.59 & 1.49 & 1.71 & 0.95 & n.a. & n.a. & n.a. & 1.50 \\
\hline
\end{tabular}

Source: Bankscope Sept, 2014.

Credit risk can also be due to staff inefficiency in handling credit management process, either in financing processing, documentation or monitoring process. Moral hazard and agency problem have been shown from previous studies to affect bank credit risk. However, little attention was given to staff efficiency in previous studies. A survey of the past literature only shows efficiency and cost efficiency relationship by Abd-Karim et al. (2010). This gap in the literature motivates the present study to focus on staff efficiency as a moderator in determining factors influencing impaired financing of Islamic banks in Malaysia. This new approach will highlight the inclusion of new macro-socio variables, such as political stability index and corruption control index. Malaysia is selected because it is the biggest hub of Islamic banks (Sufian, Mohamad Noor \& Majid, 2008). The objective of this study is to share the findings on the determinants of impaired financing with the moderating effect of staff efficiency have significantly affected the Islamic bank in the way statistically and economically significant.

\section{Research Question}

- How do external factors (gross domestic products, inflation, political stability index and corruption control index) influence the level of impaired financing among Islamic banks in Malaysia?

- What are the effects of internal factors (financing to deposit ratio, loan loss provision, liquidity ratio, capital ratio, net interest margin, profitability, loan growth and net charged off) towards the level of impaired financing among Islamic banks in Malaysia?

- Are the effects of the internal factors on impaired financing among Islamic banks in Malaysia is moderated by staff efficiency?

Significance of the Study: This study is a much needed attempt to present a comprehensive analysis of impaired financing determinants in Islamic banks involves the identification of external factors and internal factors which are associated with increases in impaired financing of Islamic bank. The effect of staff efficiency as a moderator between internal factors and impaired financing would also position the Islamic banking to cater to human resource competencies as an important tool to reduce impaired financing. This is a new dimension from the financial factor analysis aspect.

\section{Literature Review}

Khan and Ahmed (2001) revealed that one of the challenges in Islamic banking is credit risk. This risk will occur when customers fail to meet their financing obligation fully in stipulated period which is associated with the financing default. Table 2 below, shows several factors contributing to impaired financing (IF). 
Table 2: Summaries of Literature Review

\begin{tabular}{|c|c|c|c|}
\hline Author & Variables & $\begin{array}{l}\text { Relationship } \\
\text { (+ve/-ve) }\end{array}$ & Impact \\
\hline \multicolumn{4}{|l|}{ External Factors } \\
\hline \multicolumn{4}{|l|}{ Skarica(2014);Ahmed(2009); } \\
\hline Guy \& Lowe(2012) \& & Gross Domestic Products(GDP) & -ve & Significant \\
\hline \multicolumn{4}{|l|}{ Kouser \& Azeem(2012) } \\
\hline \multicolumn{4}{|l|}{ Skarica(2014); } \\
\hline Senawi \& Mat Isa(2014) \& & Inflation(INF) & $+\mathrm{ve}$ & Significant \\
\hline \multicolumn{4}{|l|}{ Nkusu(2011) } \\
\hline Boudriga, Taktak \& Jellouli(2008) & Political Stability Index(PSI) & -ve & Insignificant \\
\hline Boudriga, Taktak \& Jellouli(2008) & Corruption Control Index(CCI) & -ve & Insignificant \\
\hline \multicolumn{4}{|l|}{ Internal Factors } \\
\hline Ahmad(2007) & Finance to Deposit Ratio(FD) & + ve & Significant \\
\hline Messai \& Jouini(2013) \& & Loan Loss Provision(LLP) & + ve & Significant \\
\hline \multicolumn{4}{|l|}{$\operatorname{Ahmad}(2007)$} \\
\hline Iqbal(2012) & Liquidity Ratio(LIQR) & -ve & Significant \\
\hline Ezeoha(2011) & Capital(CAP) & -ve & Significant \\
\hline $\operatorname{Roy}(2014)$ & Net Interest Margin(NIM) & + ve & Insignificant \\
\hline \multicolumn{4}{|l|}{ Azeem \& Amara(2014); } \\
\hline Ezeoha(2011) \& & Profitability(PROFIT) & -ve & Significant \\
\hline \multicolumn{4}{|l|}{ Messai \& Jouini(2013) } \\
\hline Khemraj \& Pasha(2009) & Loan Growth(LGROW) & -ve & Significant \\
\hline Bhat, Lee \& Ryan(2013) & Net Charge Off(NCOFF) & -ve & Significant \\
\hline \multicolumn{4}{|l|}{ Moderator } \\
\hline Mat Rahim et al. (2012) \& & Staff Efficiency(STAFFX) & -ve & Significant \\
\hline Abd Karim et al. (2010) & & & \\
\hline
\end{tabular}

Related Theories to the Study: Resource-based theory explains that success in competition for the organization is based on internal and external resources owned by the organization. Staffs which are internal resource are assets to the banks and their efficiency and productivity will lead to the success of the bank. This theory postulates that when employees are highly competent and knowledgeable, they are more able to contribute towards bank efficiency, generate revenues and profit. Another related theory is theory of financial intermediation. The Islamic banking system is not only intermediaries but also an entrepreneur to manage the capital provided by the investor or capital provider. Any profit generated from the capital is shared between the capital provided and entrepreneur according to mutually agreed profit sharing ratio. This dual roles played by Islamic bank is different from conventional bank which only acts as an intermediaries. Islam is very concerned about credibility and sincerity of the staff in discharging their daily duties assigned. This was revealed in Al-Quran:

"O believers! Do not betray the trust of Allah and His Rasool, nor violate your trust knowingly" (Al-Anfal: 27).

Efficient and outstanding employees should have the integrity, potential to think, strategize, implement and achieve the level of success in discharging their duties in seeking the blessings of Allah. Staff with high credibility and efficiency would contribute to the lower default account and impaired financing to the banks.

\section{Methodology}

The research theoretical framework for this research inclusion of dependent variable, independent variable and moderating variable is as illustrated in Figure 1 below. 
Figure 1: Conceptual Framework of Islamic Banks Impaired Financing Determinants in Malaysia

\begin{tabular}{|l|l|}
\hline $\begin{array}{l}\text { Independent Variables (IV) } \\
\text { External Factors } \\
\text { Inflation } \\
\text { Political Stability Index } \\
\text { Corruption Control Index }\end{array}$ \\
\begin{tabular}{|l|l|}
\hline $\begin{array}{l}\text { Internal Factors } \\
\text { Financing to Deposit Ratio } \\
\text { Loan Loss Provision } \\
\text { Liquidity Ratio } \\
\text { Capital } \\
\text { Net Interest Margin } \\
\text { Profitability } \\
\text { Loan Growth } \\
\text { Net Charge Off }\end{array}$ & Impaired Financing \\
\hline
\end{tabular} \\
\hline
\end{tabular}

\section{Hypotheses Development}

- GDP, PSI and CCI are negatively related to IF of Islamic banks in Malaysia.

- INF has positive relationship with IF of Islamic banks in Malaysia.

- FD, LLP and NIM and NCOFF have positive relationship with IF of Islamic banks in Malaysia.

- $\quad$ LIQR, CAP, PROFIT and LGROW have relationship with IF of Islamic banks in Malaysia.

- Staff efficiency moderates the relationship between internal factors (FD, LLP, LIQR, CAP, NIM, PROFIT, LGROW \& NCOFF) with IF of Islamic banks in Malaysia.

Multiple Regression Models (Before inclusion of moderating variable)

(i) On a pool basis.

IFit $=\alpha 0+\beta 1 \mathrm{GDP}_{i t}+\beta 2 \mathrm{INF}_{i t}+\beta 3 \mathrm{PSI}_{i t}+\beta 4 \mathrm{CCI}_{i t}+\beta 5 \mathrm{FD}_{i t}+\beta 6 \mathrm{LLP}_{i t}+\beta 7 \mathrm{LIQR}_{i t}+\beta 8 \mathrm{CAP}_{i t}+\beta 9 \mathrm{NIM}_{i t}+$ $\beta 10$ PROFIT $_{i t}+\beta 11$ LGROW $_{i t}+\beta 12 \mathrm{NCOFF}_{i t}+\mathrm{e}_{i t}$

(ii) On external basis.

IFit $=\alpha 0+\beta 1 \mathrm{GDP}_{i t}+\beta 2 \mathrm{INF}_{i t}+\beta 3 \mathrm{PSI}_{i t}+\beta 4 \mathrm{CCI}_{i t}+\mathrm{e}_{i t}$

(iii) On internal basis

IFit $=\alpha 0+\beta 1 \mathrm{FD}_{i t}+\beta 2 \mathrm{LLP}_{i t}+\beta 3 \mathrm{LIQR}_{i t}+\beta 4 \mathrm{CAP}_{i t}+\beta 5 \mathrm{NIM}_{i t}$

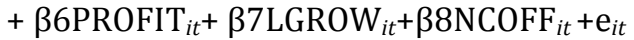
Where,

$\alpha \quad=\quad$ constant

$i \quad=\quad$ bank

$t=$ time period

$\mathrm{e}_{i t}=\quad$ Error term of bank $i$ on time $t$

Hierarchical Moderated Multiple Regression Model (With moderating variable): The equation with the moderating and interaction variables is:

IFit $=\alpha 0+\beta$ FD $_{i t}+\beta 2 \mathrm{LLP}_{i t}+\beta 3 \mathrm{LIQR}_{i t}+\beta 4 \mathrm{CAP}_{i t}+\beta 5 \mathrm{NIM}_{i t}+\beta 6 \mathrm{PROFIT}_{i t}+\beta \mathrm{H} \mathrm{LGROW}_{i t}+$ $\beta 8 \mathrm{NCOFF}_{i t}+\beta_{\text {STTAFFXit }} \beta$ 10FD $_{i t}{ }^{*} \mathrm{STAFFX}_{i t}+\beta 11 \mathrm{LLP}_{i t}{ }^{*} \mathrm{STAFFX}_{i t}+12 \mathrm{LIQR}_{i t}{ }^{*} \mathrm{STAFFX}_{i t}+\beta_{13 \mathrm{CAP}_{i t}}{ }^{*} \mathrm{STAFFX}_{i t}$ $+\beta 14$ NIM $_{i t}{ }^{*}$ STAFFX $_{i t}+\beta 15$ PROFIT $_{i t}{ }^{*}$ STAFFX $_{i t}+\beta 16$ LGROW $_{i t}{ }^{*}$ STAFFX $_{i t}+\beta 17$ NCOFF $_{i t}{ }^{*}$ STAFFX $_{i t}+\mathrm{e}_{i t}$

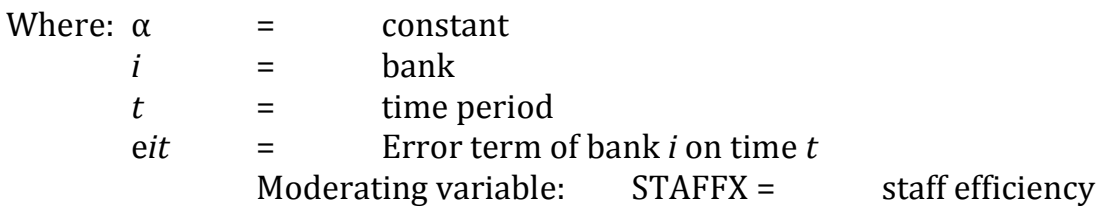


Data Collection: This study used secondary data over 2005 - 2013 periods. The sources of the data for external factors were obtained from Regional Economic Outlook. For internal and moderating factors, the data comprising financial ratios were obtained from annual reports of 16 Malaysians' Islamic banks published in bank scope database. Political stability index and corruption control index which are the new variables to be tested were extracted from World Governance Indicator Reports (Wgidataset.com).

\section{Results}

Diagnostic test result of the homoscedasticity test, auto-correlation test and penal data test is conducted and the result is presented in Table 4 below:

Table 4: Diagnostic Test for Malaysian Data

\begin{tabular}{ll}
\hline Test & (Prob $>$ F) \\
\hline Homoscedasticity/Heteroscedasticity Test & $0.0005^{* *}$ \\
Auto-correlation Test & $0.0003^{* *}$ \\
Panel Data Test(Hausman Test) & $0.0000^{* *}$ \\
\hline
\end{tabular}

Note: ${ }^{*} \mathrm{p}<0.05,{ }^{* *} \mathrm{p}<0.01$

The Breusch-Pagan test is used to detect the existence of heteroscedasticity in the model. The result in Table 4 shows that this model for Malaysia is found to be significant at $p<0.01$.The result rejected the null hypothesis and concluded that the presence heteroscedasticity in our model of Islamic bank in Malaysia. Gujarati and Porter (2010) suggested that a Lagram-Multiplier test is most suitable for serial correlation and to detect first-order autocorrelation. The multiple regression analysis is performed to examine the relationship between independent variables and impaired financing. The result of multiple regression tests are presented in Table 5.

Table 5: External and Internal Factors on Impaired Financing (IF) of Islamic Banks in Malaysia

\begin{tabular}{lcccl}
\hline Variable & Expected signs & Beta Coefficient & $\boldsymbol{t}$-statistics & $\boldsymbol{p}$-value \\
\hline GDP & - & 0.2698 & 1.8625 & 0.0667 \\
INF & + & -0.1980 & -1.8058 & 0.0752 \\
PSI & - & -0.1328 & -1.4334 & 0.1562 \\
CCI & - & -0.1296 & -1.4468 & 0.1524 \\
FD & + & 0.0037 & 0.7716 & 0.4429 \\
LLP & + & 0.0215 & 2.8267 & $0.0061^{* *}$ \\
LIQR & - & -0.0185 & -0.8791 & 0.3823 \\
CAP & - & -0.0139 & -0.3405 & 0.7345 \\
NIM & + & 0.2354 & 1.6823 & 0.0970 \\
PROFIT & - & -0.0368 & -1.3649 & 0.1767 \\
LGROW & - & -0.0178 & -2.7600 & $0.0074^{* *}$ \\
NCOFF & + & 0.0245 & 0.4209 & 0.6751 \\
R & & & & \\
Adjusted R ${ }^{2}$ & 0.8396 & & & \\
F-Statistics & 0.7754 & & & \\
Sig F-Statistics & 13.0886 & & & \\
N & 0.0000 & & & \\
\hline Note: ${ }^{*}<0.05,{ }^{* *}<<0.01$ & & & &
\end{tabular}

The F-statistic that explains the overall significance of the model is found to be significant at 0.000 level with $\mathrm{R}$ square $\left(\mathrm{R}^{2}\right)$ of 0.8396 and adjusted $\mathrm{R}$-squared of 0.7754 . It shows that the regression model consisting of GDP, INF, PSI, CCI, FD, LLP, LIQR, CAP, NIM PROFIT, LGROW and NCOFF could explain 77.54 percent in IF. Further, the predictors from external variables found to be insignificant such as, gross domestic product (GDP), inflation (INF), political stability index (PSI) and corruption control index (CCI). Meanwhile there are two significant internal variables such as, loan loss provision (LLP) and loan growth (LGROW) which support the hypotheses. Other predictors such as, finance to deposit (FD), liquidity (LIQR), capital (CAP), net interest margin (NIM), profitability (PROFIT) and net charged off (NCOFF) have no impact on impaired financing (IF) of Islamic bank in Malaysia at 0.05 . The coefficient estimation of LLP is 0.0215 with t-value of $2.8267(\mathrm{p}<0.01)$. This result indicates that a 0.0215 point increase in LLP, result in an increase of 1 point increase in IF of Islamic bank in Malaysia. The coefficient estimation of LGROW is 
-0.0178 with $\mathrm{t}$-value of $-2.7600(\mathrm{p}<0.01)$. This result indicates that a 0.0178 point decrease in LGROW, will result in an increase of 1 point in IF of Islamic bank in Malaysia. Although the result is not significant, the negative relationship between LGROW and IF appears to suggest that increase in LGROW reduces IF.

Result and Discussion on the Moderating Effects of Staff Efficiency on the Relationship between Internal Factors and Impaired Financing: Table 6 presents the result of hierarchical multiple regressions on the moderating effects of STAFFX on the relationship between internal factors (FD, LLP, LIQR, CAP, NIM, PROFIT, LGROW \& NCOFF) and impaired financing (IF) of Islamic banks in Malaysia. The result is based on Model 1, Model and Model 3.

Table 6: The Moderating Effects of STAFFX on Internal Factors and IF for Islamic Banks in Malaysia

\begin{tabular}{|c|c|c|c|c|c|c|}
\hline \multirow[t]{2}{*}{ Variable } & \multirow{2}{*}{$\frac{\text { Model 1 }}{\beta}$} & \multicolumn{4}{|c|}{ Model 2} & \multirow{2}{*}{$\frac{\text { Model } 3}{\text { p-value }}$} \\
\hline & & p-value & $\beta$ & p-value & $\boldsymbol{\beta}$ & \\
\hline FD & 0.0036 & 0.5337 & 0.0019 & 0.5550 & 0.0023 & 0.1355 \\
\hline LLP & 0.0189 & $0.0104^{* *}$ & 0.0217 & $0.0016^{* *}$ & -0.0070 & 0.6049 \\
\hline LIQR & -0.0158 & 0.3155 & -0.0102 & 0.5809 & -0.0033 & 0.8574 \\
\hline CAP & -0.0116 & 0.7437 & -0.0970 & $0.0465^{*}$ & -0.0399 & 0.3719 \\
\hline NIM & 0.3077 & $0.0010^{* *}$ & 0.2244 & $0.0002^{* *}$ & 0.1179 & $0.0252^{*}$ \\
\hline PROFIT & -0.0350 & 0.2100 & -0.0883 & $0.0026^{* *}$ & 0.0293 & 0.4928 \\
\hline LGROW & -0.0157 & $0.0186^{*}$ & -0.0161 & $0.0114^{* *}$ & -0.0037 & 0.6121 \\
\hline NCOFF & 0.0045 & 0.9241 & 0.0712 & 0.4503 & 0.1023 & 0.2366 \\
\hline STAFFX & & & -0.0620 & $0.0003^{* *}$ & 0.0530 & 0.1403 \\
\hline FDSTAFFX & & & & & 0.0002 & 0.8362 \\
\hline LLPSTAFFX & & & & & 0.0007 & $0.0215^{*}$ \\
\hline LIQRSTAFFX & & & & & -0.0003 & 0.8206 \\
\hline CAPSTAFFX & & & & & -0.0079 & $0.0000^{* *}$ \\
\hline NIMSTAFFX & & & & & 0.0053 & 0.0977 \\
\hline PROFITSTAFFX & & & & & -0.0045 & $0.0000^{* *}$ \\
\hline LGROWSTAFFX & & & & & -0.0005 & $0.0000^{* *}$ \\
\hline NCOFFSTAFFX & & & & & -0.0012 & 0.7960 \\
\hline $\mathrm{R}^{2}$ & \multicolumn{2}{|c|}{0.8202} & \multicolumn{2}{|c|}{0.8593} & \multicolumn{2}{|c|}{0.8889} \\
\hline Adjusted $\mathrm{R}^{2}$ & \multicolumn{2}{|c|}{0.7619} & \multicolumn{2}{|c|}{0.8111} & \multicolumn{2}{|c|}{0.8325} \\
\hline $\mathrm{R}^{2}$ Change & & & \multicolumn{2}{|c|}{0.0391} & \multicolumn{2}{|c|}{0.0296} \\
\hline Sig F-Statistics & \multicolumn{2}{|c|}{0.0000} & \multicolumn{2}{|c|}{0.0000} & \multicolumn{2}{|c|}{0.0000} \\
\hline F-Statistics & \multicolumn{2}{|c|}{14.0685} & \multicolumn{2}{|c|}{17.8366} & \multicolumn{2}{|c|}{15.7615} \\
\hline
\end{tabular}

Note: ${ }^{*} \mathrm{p}<0.05,{ }^{* *} \mathrm{p}<0.01$

Model 1: In model 1, internal variables (FD, LLP, LIQR, CAP, NIM PROFIT, LGROW and NCOFF) are found to be significant at 0.000 levels with adjusted $\mathrm{R}^{2}$ of 0.7619 . There are three predictors, which are significant, LLP $(\beta=0.0189, \mathrm{t}=2.6283, \mathrm{p}<0.01)$, NIM $(\beta=0.3077, \mathrm{t}=3.4160 \mathrm{p}<0.01)$ and LGROW $(\beta=-$ $0.0157, \mathrm{t}=-2.4057, \mathrm{p}<0.05)$. Other predictors such as, FD, LIQR, CAP, PROFIT and NCOFF have no impact on IF of Islamic banks in Malaysia.

Model 2: In model 2, the moderating variable namely staff efficiency (STAFFX) is included. The result presented in the Table 6 shows that this model was found out to be significant at the 0.000 level with adjusted $R^{2}$ of 0.8111 . There are six predictors found to be significant, $L L P(\beta=0.0217, t=3.2818 p<0.01)$, CAP $(\beta=-0.0970, t=-2.0250, p<0.01)$, NIM $(\beta=0.2244, t=3.9782, p<0.01)$, PROFIT $(\beta=-0.0883, t=-3.1164$, $\mathrm{p}<0.01)$, LGROW $(\beta=-0.0161, \mathrm{t}=-2.5957, \mathrm{p}<0.01)$ and STAFFX $(\beta=-0.0620, \mathrm{t}=-3.8319, \mathrm{p}<0.01)$. Other predictors such as, FD, LIQR and NCOFF are insignificant.

Model 3: Model 3 shows the result of the interaction variables (FD, LLP, LIQR, CAP, NIM, PROFIT, LGROW, NCOFF, STAFFX, FD*STAFFX, LLP*STAFFX, LIQR*STAFFX, CAP*STAFFX, NIM*STAFFX, PROFIT*STAFFX, LQROW*STAFFX \& NCOFF*STAFFX) which is to test the moderating effect of staff efficiency on IF of Islamic banks. The result presented in the Table 6 shows that this model 3 to be significant at the 0.000 level with adjusted $\mathrm{R}^{2}$ of 0.8325 . The model could explain 83.25 percent in IF. There were only four interaction variables significant such as LLP*STAFFX, CAP*STAFFX, PROFIT*STAFFX and LGROW*STAFFX.

The significant relationship of staff efficiency as a moderator is depicted in Figure 2, 3, 4 and 5 below: 


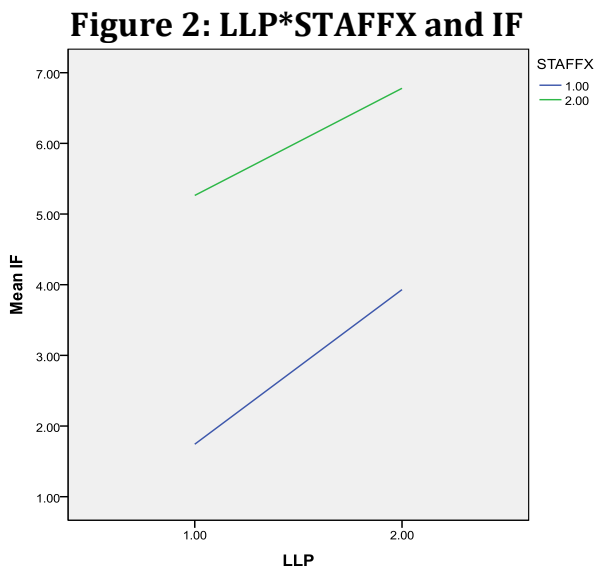

Figure 4: PROFIT*STAFFX and IF

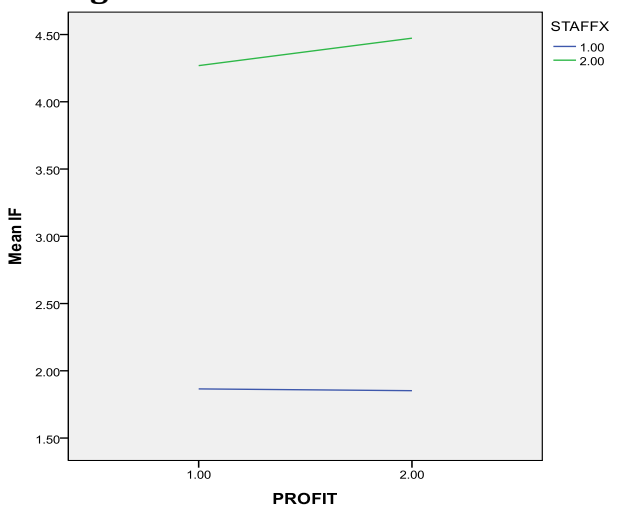

Figure 3: CAP*STAFFX and IF

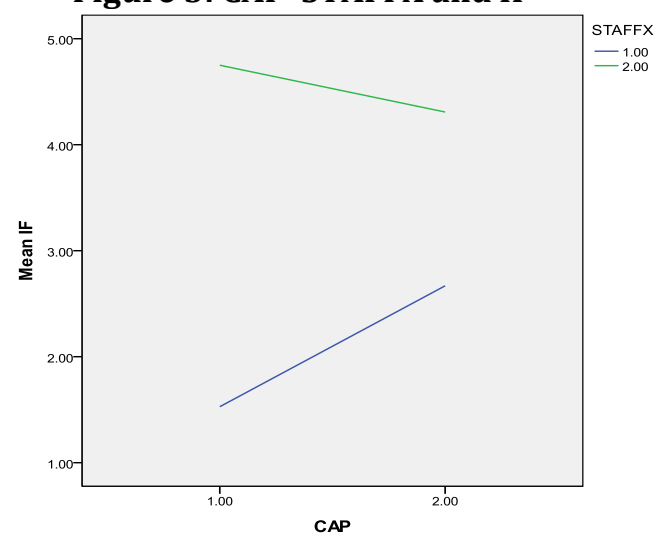

Figure 5: LGROW*STAFFX and IF

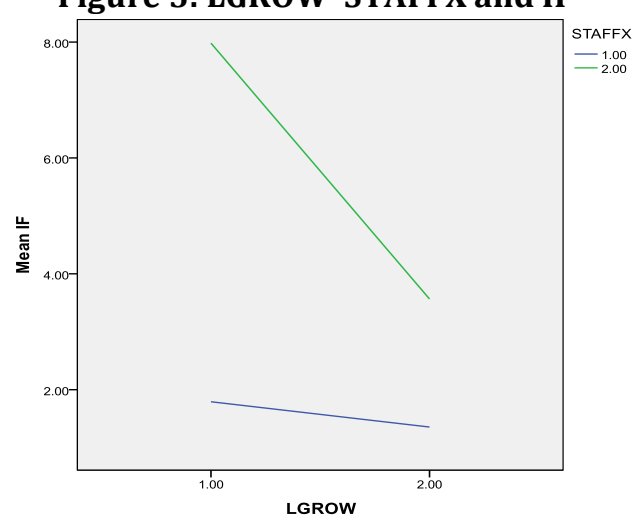

\section{Conclusion}

This paper concludes the result that external factors such as GDP, inflation, political stability index and corruption control index were not significant in influencing impaired financing of Islamic banks in Malaysia. Meanwhile, only loan loss provision and loan growth were the determinants of impaired financing of Islamic banks in Malaysia. On the other hand, it is found that staff efficiency moderate negatively and significantly the impact of loan loss provision, capital, profitability and loan growth. These result imply that the higher in the staff efficiency in their work, the lower in the impaired financing. In other words, staff efficiency in allocating loan loss provision and managing capital would contribute significantly to reduction in impaired financing of Islamic banks. Reduction in impaired financing could also be achieved when staff is efficient in assessing, selecting, monitoring and controlling the expended loan portfolio or loan growth. In contrast, the negative significant impact of staff efficiency and profit on impaired financing of Islamic banks appears to suggest that staff efficiency is crucial to reduce impaired financing which consequently result in higher profit.

Contribution of the Study: This study provides empirical evidence that Islamic banks with their profit and loss and risk sharing concept are not extremely affected by macro-economic factors. This finding is in contrast to the result of Hasan and Lehar (2009); Ahmad (2003) and Ranjan and Dhal (2003) which found that macro-economic factors such as GDP and inflation are significantly influence impaired financing of the conventional banks. Another new contribution is the moderation effect of staff efficiency, which has not been analyzed before. The high significant level (0.01) of the impact of staff efficiency on reducing impaired financing suggested clearly that banks' management should give equal emphasis on increasing the level of staff efficiency besides looking at the financial factors in mitigating credit risk.

Suggestion for Future Research: There is a lot more related field that can be studied for the future research in the Islamic banks system. Impaired financing of Islamic banks remain an important issue in financing activities of Islamic banks. In order to remain equally competitive to their conventional counterparts, Islamic banks should continue to emphasize on impaired financing management and risks management. Hence, future studies are recommended to include robust model which include customers' behavior towards financing preference. A cross-country comparison on impaired financing of Islamic 
banks especially focusing on Islamic economic blocks such as in OIC countries, GCC and emerging market is highly needed to contribute to the scant literature on Islamic banking studies.

\section{References}

Abd-Karim, M. Z., Chan, S. G. \& Hassan, S. (2010). Bank efficiency and non-performing loans: Evidence from Malaysia and Singapore. Prague Economic Papers, 2(1).

Ahmad, N. H. (2007). Multi country study of bank credit risk determinants. The International Journal of Banking and Finance, 5(1).

Ahmad, N. H. (2003). Formation of credit risk, regulatory price effect and the path linking credit to total risk Unpublished Doctor of Philosophy Thesis, University Utara Malaysia.

Ahmad, N. H. \& Ahmad, S. N. (2004). Key factors influencing credit risk of Islamic bank: a Malaysian case. Journal of Muamalat and Islamic Finance Research, 1(1).

Ahmed, H. (2009). Financial crisis: risks and lessons from Islamic finance. ISRA International Journal of Islamic Finance, 1(1).

Al-Quran. (2001). Translated by Muhammad Farooq-i-Azam Malik, the Institute of Islamic Knowledge, Houston, Texas, USA (March, 2001).

Azeem, A. \& Amara, K. (2014). Impact of profitability on quantum of non-performing loans. International Journal of Multidisciplinary Consortium, 1(1).

BNM (Bank Negara Malaysia). (2013). Monetary and financial developments February 2013. Siaran Akhbar.

BNM (Bank Negara Malaysia). (2012). Guideline on skim perbankan Islam. BNM/RH/GL001-27.

BNM (Bank Negara Malaysia). (2012). Quarterly statistical report, September 2012.

BankScope Database, https://bankscope2.bvdep.com/version-2012713/

Ben Ameur, I. G. \& Mhiri, S. M. (2013). Explanatory factors of bank performance evidence from Tunisia. Journal of Economic, Finance and Management, 2(1).

Bhat, G., Lee, J. \& Ryan, S. G. (2013). Utilizing loan loss indicators by loan type to sharpen the evaluation of the information content and economic consequences of banks' loan loss reserving. Bhat Paper, October 2013.

Boudriga, A. K., Taktak, R. B. \& Jellouli, S. (2008). Problem loans in the MENA countries: Bank specific determinants and the role of the business and the institutional environment. Forthcoming, Bankers, Market and Investors, DEFI, Tunis University.

Brigham, E. F. \& Ehrhardt, M. C. (2003). Financial Management: Theory and Practice (10 th ed.). SouthWestern, Thomson Learning, USA

Chapra, M. U. (2008). The global financial crisis: Can Islamic finance help minimize the severity frequency of such a crisis in the future? Paper presented at the Forum on the Global Financial Crisis held at the Islamic Development Bank on 25 October 2008.

Ezeoha, A. E. (2011). Banking consolidation, credit crisis and asset quality in a fragile banking system: Some evidence from Nigeria data. Journal of Financial Regulation and Compliance, 19(1), 33-44.

Gujarati, D. N. \& Porter, D. C. (2010). Essentials of Econometrics (4th Ed.) Mc Graw-Hill.

Hasan, Z. \& Lehar, H. (2009). Macroeconomics. Oxford University Press, New York, USA.

Iqbal, A. (2012). Liquidity risk management. A comparative study between conventional and Islamic banks in Pakistan. Global Journal of Management and Research, 12(5).

ICAP (2006). Financial ratios explanation. ICAP Group S.A. October 2006.

Kaufmann, D., Kraay, A. \& Mastruzzi, M. (2010). The worldwide governance indicators: A summary of methodology, data and analytical issues. World Bank Policy Research Working Paper No. 5430.

Khan, T. \& Ahmed, H. (2001). Risk management: An analysis of issues in Islamic financial industry. Occasional Paper No. 5. Jeddah, Saudi Arabia: Islamic Research Training Institute of Islamic Development Bank.

Khan, F., Anuar, A. M., Choo, L. G. \& Khan, H. (2011). Determinants of bank profitability in Pakistan: A case study of Pakistan banking sector. World Applied Science Journal, 15(10), 1484-1493, ISSN 18184952

Khemraj, T. \& Pasha, S. (2009). The determinants of non-performing loans: An econometric case study of Guyana. MPRA Paper No. 53128.

Laeven, L. \& Valencia, F. (2008). The use of blanket guarantees in banking crises. IMF WP, 08/250.

Mat-Rahim, S. R., Mohd Hassan, N. \& Zakaria, R. H. (2012). Islamic vs conventional bank stability: A case study of Malaysia. Prosiding PERKEM, VII (2), 839-850

Messai, A. S. \& Jouiui, F. (2013). Micro and macro determinants of non-performing loans. International Journal of Economics and Financial Issues, 3(4), 852 -860. 
Mohd-Sultan, S. A. (2008). Islamic banking: Trend, development and challenges. Essential Readings in Islamic Finance, CERT Publications Sdn. Bhd.

Nkusu, M. (2011). Nonperforming loans and macro financial vulnerabilities in advanced economics. IMF Working Paper, WP/11/161.

Ranjan, R. \& Dhal, S. C. (2003). Non-performing loans and terms of credit of public sector bank in India: An empirical assessment. Reserve Bank of India Occasional Papers, 24(3).

Rose, P. S. (2002). Commercial Bank Management (5 ${ }^{\text {th }}$ d.). Boston: McGraw-Hill.

Roy, S. G. (2014). Determinants of non-performing assets in India - Panel Regression. Eurasian Journal of Economics and Finance, 2(3), 69-78.

Senawi, A. R. \& Mat-Isa, M. P. (2014). Gold price as a determinant of non-performing loans: An analysis of Malaysia. Global Business and Management Research: An International Journal, 6(4).

Skarica, B. (2014), Determinants of non-performing loans in Central and Eastern European countries. Financial Theory and Practice, 38(1), 37-59.

Sufian, F., Mohamad-Noor, M. A. \& Abdul Majid, M. Z. (2008). The efficiency of Islamic bank: Empirical evidence from MENA and Asian countries Islamic banking sectors. MPRA Paper No. 19072, June 2008.

World Bank (2014). www.wgidataset.com

\section{Appendix 1}

\section{Operational Definition and Measurement}

\begin{tabular}{|c|c|c|}
\hline Variables & Operational Definition/Measurement & Source \\
\hline Impaired Financing (IF) & $\frac{\text { Non-Current Financing }}{\text { Total Financing }}$ & Rose (2002) \& Ahmad (2003) \\
\hline Gross Domestic Product (GDP) & Based on aggregate of economic activity & $\begin{array}{l}\text { Hasan and Lehar (2009) \& } \\
\text { World Bank (2014) }\end{array}$ \\
\hline Inflation (INF) & Consumer price index & $\begin{array}{l}\text { Ben Ameur and Mhiri, (2013) } \\
\text { \& World Bank (2014) }\end{array}$ \\
\hline Political Stability Index (PSI) & $\begin{array}{l}\text { Based on ranking ranges from } 0 \text { (low political } \\
\text { stability) to } 100 \text { (high political stability). }\end{array}$ & $\begin{array}{l}\text { Kaufmann, Kraay\& Mastruzzi } \\
\text { (2010) \& World Bank (2014) }\end{array}$ \\
\hline Corruption Control Index (CCI) & $\begin{array}{l}\text { Based on ranking ranges from } 0 \text { (high corruption) } \\
\text { to } 100 \text { (highly clean from corruption). }\end{array}$ & $\begin{array}{l}\text { Kaufmann, Kraay \& Mastruzzi } \\
\text { (2010) \& World Bank (2014) }\end{array}$ \\
\hline Financing to Deposit Ratio (FD) & $\frac{\text { Total Financing }}{\text { Total Deposit }}$ & Ahmad (2003) \& Bankscope \\
\hline Loan Loss Provision (LLP) & $\frac{\text { Loan Loss Provision }}{\text { Net Interest Revenue }}$ & Ahmad (2003) \& Bankscope \\
\hline Liquidity Ratio (LIQR) & $\begin{array}{l}\text { Net Financing } \\
\text { Total Assets }\end{array}$ & $\begin{array}{l}\text { Brigham and Ehrhardt (2003) } \\
\text { \& Bankscope }\end{array}$ \\
\hline Capital Ratio (CAP) & $\frac{\text { Equity }}{\text { Total Assets }}$ & $\begin{array}{l}\text { Brigham and Ehrhardt (2003) } \\
\text { \& Bankscope }\end{array}$ \\
\hline Net Interest Margin (NIM) & $\frac{\text { Interest Income - Interest Expenses }}{\text { Total Assets }}$ & $\begin{array}{l}\text { Khan, Anuar, Choo and } \\
\text { Khan (2011) \& Bankscope }\end{array}$ \\
\hline Profitability (PROFIT) & $\frac{\text { Interest Income on Loans }}{\text { Average Gross Loans }}$ & $\begin{array}{l}\text { Ben Ameur \& Mhiri(2013) } \\
\text { \& Bankscope }\end{array}$ \\
\hline Loan Growth (LGROW) & $\frac{\text { Current year - Previous year total loan }}{\text { Previous year total loan }}$ & $\begin{array}{l}\text { Ben Ameur \& Mhiri (2013) } \\
\text { \& Bankscope }\end{array}$ \\
\hline Net Charge Off (NCOFF) & $\frac{\text { Net Charged Off }}{\text { Gross Financing }}$ & $\begin{array}{l}\text { Bhat, Lee \& Ryan (2013) } \\
\text { \& Bankscope }\end{array}$ \\
\hline Staff Efficiency (STAFFX) & $\frac{\text { Personnel Expenses }}{\text { Net Interest Income }}$ & $\begin{array}{l}\text { ICAP (2006) } \\
\text { \& Bankscope }\end{array}$ \\
\hline
\end{tabular}

